\title{
A NEW CULTURE OF TRUTH? ON THE TRANSFORMATION OF POLITICAL EPISTEMOLOGIES SINCE THE 1960S IN CENTRAL, EASTERN, AND SOUTH- EASTERN EUROPE
}

Friedrich Cain

University of Erfurt

Dietlind Hüchtker

University of Vienna

Bernhard Kleeberg

University of Erfurt

Jan Surman

Independent Scholar

Truth has become a fiercely contested subject. Shaped by the experience of insecurity, the first half of the year 2020 has put the process of "truth in the making" on display in conditions of a global pandemic: quite often "In truth we trust" seems to be equated with "In science we trust" (Carolan $\&$ Bell 2003). At the same time, the truth people trust in seems to have multiplied: they do not have trust in the truth, but in a particular truth.

The COVID-19 crisis, which is likely the first globally mediatised health crisis in history, allows us to observe the relations of societies and science in a condensed form. We can spot how "science in the making" is

1 For the theoretical distinction between "science in the making" and "science already made" see Bruno Latour and Steve Woolgar's influential book (1979). Sociologists and historians of science 
put under pressure and how modes of scientific reasoning have to be defended against a public need for immediate results and clear-cut, universal solutions. We can see how preliminary results are being widely applied and how competing truths are based on partial data, on outcomes that have not been peer-reviewed, ${ }^{2}$ or on work in progress which is mistaken for scientific results. Sometimes the premature acknowledgement of pre-peerreview articles - before their rejection a few weeks later (Rabin \& Gabler 2020; Redden 2020) - seems to have paved the way for these new cultures of truth, since what scientists regarded as methodologically faulty almost automatically turned into "truth" 3 for an anti-academic public.

The pandemic has not only abridged the maturation process of scientific information - which now seems to turn immediately into scientific truth - it has also strengthened the expert as the figure who invents, mediates, and formulates the truth. Of course, these experts, the subjective faces of pandemic prevention, differ from country to country: for instance, in Germany it was Charité virologist Christian Drosten, in Sweden - the State Epidemiologist, Anders Tegnell, in Poland - the Minister of Health, Lukasz Szumowski, and in Russia - the Mayor of Moscow and head of the Working Group of the State Council for the Fight against Coronavirus, Sergey Sobyanin. This list, as incomplete as it is, signals not only a close connection between science and politics, but a close connection between the objective and subjective side of truth, between truth cultures and truth figures: in order to be acknowledged as experts, these physicians, politicians, or apt administrators have to rely on long-standing cultural assumptions about who can be a person of trust at all. ${ }^{4}$

have long made the connection between the reliability of science and the need not to treat science as a black box but to look at the processes inside it. See, for one of the early claims, Steven Shapin's "Why the Public Ought to Understand Science-in-the-Making" (1992). For studies of the complex processes of drawing and writing, see the works of the research initiative Knowledge in the Making (Hoffmann 2008; Krauthausen \& Nasim 2010; Wittmann 2009). On emerging modes of knowledge-making in pandemics, see Lorraine Daston's post (2020).

2 While many noted White House press secretary Kayleigh McEnany's (in)famous statement that "[t]he science should not stand in the way of opening the schools," not many looked into how McEnany substantiated this statement, namely with reference to the Journal of the American Medical Association's paediatric study claiming that the risk from COVID-19 to children is comparable to that of the seasonal flu (see Yeung et al. 2020). The issue of pre-peer-review publications, which began as a way to facilitate the swift exchange of information, is itself worthy of special study.

${ }^{3}$ For instance, in Germany such a conflict arose about the interpretation of reliable data. See the public conflicts between Hendrick Streeck, Alexander Kekulé, and Christian Drosten, which have been described as Virologen-Streit.

${ }^{4}$ In the last two examples, Poland and Russia, the opposition also recognised Szumowski and Sobyanin to be "apolitical," at least until the "flattening of the curve" and the relaxation of sanitary regimes. No significant oppositional or scientific counter-experts could be identified. 
Thus the most lasting image of the COVID-19 pandemic may not be the grey-red image of the virus currently flooding the social networks. It may well be the image of joint press conferences in which Donald Trump and Anthony Fauci, side by side, represented different cultures of truth: both had their arguments, of better or worse nature, and both aimed their statements at a particular public. Tellingly, Fauci presented scientific information which indicated uncertainty, while Trump presented a populist truth that aimed at providing certainty for his voters in an election year. Both related science to uncertainty, albeit following a different logic and using different rhetoric - Fauci pointed out that science is uncertain by nature; Trump took uncertainty within the scientific community as a justification for questioning scientific credibility. ${ }^{5}$ Trump and Fauci obviously represent two opposing cultures of truth: one in which the subject narcissistically believes in his own intellectual power and juxtaposes the elevated common sense of the self-made man with a scientific rationality conceived of as elitist and egotist; the other believing in the power of science. Both figures also stand for two different ways of mediating truth: the politician making short, firm, and decisive statements; the scholar translating scientific incompleteness and uncertainty into widely understandable health instructions. Trump tweets - with the White House staff giving explanations - while Fauci gives long interviews in a language full of what linguists call hedging. ${ }^{6}$

The COVID-19 situation opens up the possibility of studying truth practices as if they were under a burning glass: it highlights strategies of trust- and belief-making; it highlights the role of the media and the public, the role of translation and context, and, last but not least, the role of specific figures who step into the centre of truth-making processes. However, the global fragmentation of truth cultures is older than the pandemic. In several countries, the political parties in power have successfully started to restructure all parts of society as well as the media reporting on it, and they have also started to restructure the sciences and humanities: rearranging legal departments, banning discourses and even specific disciplines, such as gender studies, reorganising university funding, and changing evaluation criteria. And, at the same time, they have started to attack crucial elements of scientific truth regimes. This has massive consequences not only for the

\footnotetext{
${ }^{5}$ On the history of blurring scientific results as a strategy to question their validity, see Naomi Oreskes and Erik M. Conway's study (2010).

${ }^{6}$ On different ways of hedging between scientists and politicians, see Priya Venkatesan Hays's chapter (2016).
} 
sciences and humanities themselves but for international politics as well, since common epistemological values (truthfulness, reliability, robustness, etc.) and categories (facts, objectivity, etc.) are being questioned that (used to) base consensus-building on the integration of different interests (Reckwitz 2019).

This epistemic constellation needs to be studied from a specific analytical perspective, which is developed in the current issue of Stan Rzeczy [State of Affairs]. Instead of re-echoing classic truth theories, we suggest a praxeology of truth, with its parameters of "truth scenes" and "truth figures" (Kleeberg \& Suter 2014). With this praxeological approach to "doing truth" we intend to investigate the (situational) settings in which truth is claimed or denied, and to inquire into the subjective consequences of subscribing to or avowing a truth, as well as into the social and political consequences of adhering to "the truth." In this issue, we are thus concerned with the deliberate adherence to truth that has become a very influential tactic in what has been called the "post-truth era." Whereas with reference to the United States and Western Europe this has been diagnosed as a crisis, ${ }^{7}$ in post-Soviet Europe it has been analysed as part of an ongoing process of post-Marxist pluralisation, given the lack of a sustainable, democracy-based truth tradition (Grigoryev 2011; Levinson 2004; Roudakova 2017). The destabilisation of familiar epistemologies and the dismissal of established gatekeepers is a global phenomenon with a long history but differing intensities, to which various degrees of scholarly attention have been paid.

This issue is the outcome of various talks and workshops of our research initiative (East) European Epistemologies, founded in Erfurt in 2017. Initially, the initiative aimed to study the contributions to science studies of authors from Central, Eastern, and South-Eastern Europe and to situate them within their political contexts. Starting with consideration of the first half of the twentieth century, ${ }^{8}$ the initiative widened its scope to take into account broader social and political phenomena, which also made it possible to look at more recent events, seeing them, however, in a historical, longue durée perspective. The texts in this issue trace certain genealogies in an area of the world where negotiating truth has a specific history. Truth discourses have not only been powerful since 1989, but also before that date. Thus, when the Marxist truth regime broke down and Marxism,

\footnotetext{
${ }^{7}$ For a recent discussion of the crisis of democracy and what it means to be post-truth, see Johan Farkas and Jannick Schou's book (2020).

${ }^{8}$ For a first publication, see the special section "Past and Present of Political Epistemologies of (Eastern) Europe" in Historyka. Studia Metodologiczne, vol. 49 (2019).
} 
during the transformation, lost its official monopoly on interpretation, an already ongoing process may solely have been intensified.

We want to focus on the region of Central, Eastern, and South-Eastern Europe. The mostly post-socialist countries have not been spared the emergence of new political epistemologies that follow the truth regimes of specific groups. Often, these groups are nationalist, chauvinist, and xenophobic; often the epistemologies are appropriated from abroad, and equally often they emerge as pan-regional ones, or entangled ones. They are produced by private, semi-official, or even governmental brokers, and spread via both traditional media (such as television and newspapers) and new media, such as Facebook, Vkontakte, Twitter, Instagram, or recently TikTok.

In a number of post-Soviet countries, political parties have striven since the 1990s to rearrange the social and media landscape to their liking. Recently, however, this process has also reached institutions that had long and consensually been acknowledged to be non-political and whose autonomy was supposed to guarantee their impartiality in their respective search for truth: the legal system, as well as science and scholarship (compare, e.g., Halmai 2019; Pető 2020; Zoltán et al. 2020). At the same time, crucial elements of modern truth regimes have been questioned - with the abovementioned massive consequences for the sciences and humanities, and for politics as well. What seems to be the severely dystopian nature of modern rationality could be described as a patchwork of epistemic landscapes over which many smaller skirmishes and larger turf wars are being fought.

While activities like art and architecture have long been underscored as media which embody, support, and even produce particular truths about the past, the present, or the future (see, e.g., Groys 1992 [1988]; Petrov 2011), a more recent phenomenon can help visualise the complexity of processes in which adherence to the truth serves social integration: the "Immortal Regiment" (Bessmertniy Polk), which was originally a private initiative and from 2015 has been headed by Vladimir Putin, and the "Return of the Names" (Vozvraŝenie Imën), organised by the Moscow Memorial society, are emotion-based mass events representing two contesting memories of Russia. In the latter event, individuals read out the names of victims of Soviet persecution; in the former, participants march with pictures of relatives involved in the Second World War. Not only is a particular sense of community created but also a historical myth emerges about the genealogy of post-Soviet Russia, which has to deal with crimes of the past or which proudly carries the banner of survivors of the Leningrad siege (Fedor 2017; Smith 2019). 
Phenomena like these have been analysed by Ulrich Schmid, who has studied how Russian society is influenced and formed under the media and political conditions of the twenty-first century via "political technology." To this end, he analyses historical concepts of truth in Russian culture, their connections with ideologies, emotions, and historical images, their literary and artistic "fabrication," their media presentation, advertising and PR mechanisms, and the relation between lies and reality (Schmid 2015). His reflections on "truth" as a political medium used by a dictatorial state are convincing, and he makes the comparison with Western democracies, where PR, spin doctors, and ideologies exist as well, but where additional mechanisms of controlling and correcting (and further truth figures) are in place (ibid.: 15). Nevertheless, this brief but fundamental distinction leaves the reader feeling somewhat helpless in the face of the growing dissemination of knowledge and science by the media, populist interpretations of facts, and the rise of populist leaders (see, e.g., Ehlers \& Zachmann 2020).

An investigation of this multitude of phenomena needs a new analytical framework. In the first article, Bernhard Kleeberg argues that truth is a social operator and proposes to quit philosophising about it and to start observing the social effects of invoking it, along the lines of a praxeology of truth. Presenting truth scenes and truth figures as basic parameters, the praxeological view regards truth theories as a subject of investigation only if they are part of a group's self-reflection, and not for their definition value. Rather than asking about the form and existence of truth, a praxeology of truth has to dedicate itself to a microanalysis of specific settings and scripts, subjects and virtues, places and practices of doing truth. At the same time, it aims to understand the advocacy of truth as a technique of (identity) politics in order to enable more effective forms of dealing with them. A praxeological approach allows concepts of truth to be historicised in different arenas beyond the East-West dichotomy, or for political systems to be generalised while nevertheless taking differences and contexts into consideration.

Recently, we have seen new truth figures emerge to join classic figures, such as scientists, journalists, or artists. Whistleblowers and debunkers (but also trolls) occur in their very own constellations and dwell in places that appeared during the establishment of Web 2.0. However, the set of truth figures is very dynamic, and the countries of Central, Eastern, and South-Eastern Europe are quite illustrative cases as they experienced multiple regimes (and regime changes) during the twentieth century. One very distinct truth figure that rose to prominence during the 1970s was 
"the dissident." It could be argued that this figure came to be hollow after the fall of the Soviet Union. However, "the dissident" did not become a completely empty figure as both liberal and populist politics readily appeal to their dissident pasts and reappropriate that past for their rhetoric. New truth scenes have emerged as well: the infamous Stalinist show trials took the cultural technique of confession to its dismal extremes, with farreaching consequences for the political culture of post-Soviet countries. Truth scenes incorporate a wide range of institutions (e.g., the court, the party, the fact-finding team), sites, or truth spots (Gieryn 2018; the confessional, the laboratory, the street), and practices, techniques, and media (algorithms, rhetoric, the live-stream) which change over time: they emerge, disappear, replace other institutions and practices, and get replaced. It would be a mistake to simply identify the "crisis" of absolute, uniform truth - be it scientific, juridical, journalistic, economic, or political - with the arrival of new media, which provide a multitude of truths. Instead, the problem starts from the assumption that we are witnessing truth competitions.

With their interest in political epistemologies, the contributions to this issue connect to a special issue of Historyka (Cain et al. 2019). Yet in focusing on truth, they lead through a variety of truth scenes with different truth figures across different truth regimes, from Stalinist processes to the contemporary \#MeToo movement in Polish social media. What unites them is their interest in the specific situations in which truth statements are expressed or contested, accepted or rejected - frequently in connection with a political situation. They demonstrate that current conflicts about truth are more than debates about new truth practices, more than conflicts of interest or an emotional state of affairs; they are about politics, about the establishment of power.

Anna Shor-Chudnovskaya uses a close reading of Veniamin Kaverin's memoir Epilogue (1989) and Lydia Chukovskaya's novella Sofia Petrovna (late 1930s, first published in 1965) to analyse how the Stalinist Terror of the late 1930s disconnected truth from logical understanding. She retraces how show trials led to confessions made under duress and to the detachment of "the people" from the ruling classes or from "the system," which was perceived as corrupt anyway. The author analyses how personal experiences were connected to truth and lies in different ways and how the protagonists lost the ability to clearly distinguish between them. As she suggests, this had long-standing consequences for political culture and produced

\footnotetext{
9 See Anna Shor-Chudnovskaya's article in this issue.
} 
the reluctance of people today in regard to political participation. Political reality lost its connection to logic and evidence and has never regained it.

Andreas Langenohl backs this argument in his analysis of the "imaginary" of state-socialist elections and links it to recently observed phenomena during elections in liberal democracies. These phenomena have been overlooked in many theories of political participation. Using the concept of the "imaginary," he analyses practices of voting as affording truths that lead to the better understanding of societies. He shows the factual heterogeneity of the act of voting in the Soviet Union, where elections were of practical importance, though not in the sense of theories of liberal democracy. He suggests widening the analytical categories for studying liberal elections in order to make sense of attitudes that run counter to classic ideas about voting.

Thari Jungen tells a similar story, in which classic democratic practices, with stable status in academic analysis (e.g., US elections), are destabilised when they are appropriated in order to be twisted. In her account of the manufacture of hoaxes in the small North Macedonian town of Veles, she shows how the purely economic interest of local fake-news producers opened up possibilities for alt-right agendas to outplay the truth, for example, during the 2016 presidential elections in the United States. Jungen points to the critical connection between hoaxes, fakes, commodification, and right-wing appropriation, which has often been underestimated in the academic debate, where memes and similar practices receive more attention. She stresses the ambiguity of fake news' position between popular culture and ideology and defines a hoax as a materialised lie challenging the legitimacy of existing power relations.

Anna Grutza analyses media truth practices in connection with Radio Free Europe (RFE), a broadcasting station which was appreciated for its truthful reporting by its secret listeners in the socialist states. The author focuses on the procedures installed at RFE to ensure the truthfulness of the programme and shows how technology, review and interview processes, collections and connotations (of socialism, democracy, etc.) were intertwined in truth scenes. A news item broadcast by the network was thus the product of various processes by which highly subjective reports were checked for their reliability and gradually turned into facts. In so doing, the atmosphere of objectivity associated with RFE was crucial for debunking the network of lies and the non-information or disinformation of socialist regimes. 
Finally, Paweł Bagiński analyses tactics of truth-speaking (or writing) at the time when \#MeToo (\#JaTeż) went viral in Polish Facebook commentaries (16-20 October 2017). He uses the Foucauldian concepts of parrhesia and confession to understand how female commenters used the social network to counteract the mechanisms of the patriarchal dispositive. He shows how systemic violence against women becomes a topic of truth scenes and how this not only makes the violence visible but also provokes adherents of the dispositive under attack to resort to defence mechanisms. Thus, Bagiński shows the critical importance of social media for making social problems visible, but he also hints at the fragility of newly emerging truth figures.

The articles highlight various practices of making various truths. ShorChudnovskaya's and Langenohl's starting point is the Soviet Union. Shor-Chudnovskaya emphasises the new cultures of truth in the political epistemologies of the Stalinist period. Langenohl analyses the voter as a truth figure and voting as a truth-making practice. Grutza, Jungen, and Bagiński study various media as truth spots. While Grutza focuses on the radio and highlights practices of building a truth scene, Jungen and Bagiński concentrate on social-media formats. They analyse the power of aesthetics and language as tools for establishing and evoking a truth. Together, the articles show the changing roles of truth scenes and truth spots and especially emphasise the transformations of political epistemologies.

Berlin, Vienna, Erfurt, Frankfurt/Main 2020

Bibliography:

/// Cain F., Kleeberg B., Surman J. 2019. "The Past and Present of Political Epistemologies of (Eastern) Europe," Historyka. Studia Metodologiczne, vol. 49, pp. 7-13, https://doi.org/10.24425/hsm.2019.130572.

/// Carolan M.S., Bell M.B. 2003. "In Truth We Trust: Discourse, Phenomenology, and the Social Relations of Knowledge in an Environmental Dispute," Environmental Values, vol. 12(2), pp. 225-245, https://doi. org/10.3197/096327103129341306.

/// Daston L. 2020. "Ground-Zero Empiricism," Critical Inquiry, https:// critinq.wordpress.com/2020/04/10/ground-zero-empiricism/, accessed 20.07.2020. 
/// Ehlers S., Zachmann K. 2020. "Wissen und Begründen: Evidenz als umkämpfte Ressource in der Wissensgesellschaft. Einleitung," [in:] Wissen und Begründen. Evidenz als umkämpfte Ressource in der Wissensgesellschaft, eds. S. Ehlers, K. Zachmann, Nomos, pp. 9-29, https://doi. org/10.5771/9783748903383.

/// Farkas J., Schou J. 2020. Post-Truth, Fake News and Democracy: Mapping the Politics of Falsehood, Routledge, https://doi.org/10.4324/9780429317347.

/// Fedor J. 2017. "Memory, Kinship, and the Mobilization of the Dead: The Russian State and the 'Immortal Regiment' Movement," [in:] War and Memory in Russia, Ukraine and Belarus, eds. J. Fedor, M. Kangaspuro, J. Lassila, T. Zhurzhenko, Palgrave Macmillan, pp. 307-345, https://doi. org/10.1007/978-3-319-66523-8_11.

/// Gieryn Th.F. 2018. Truth Spots: How Places Make People Believe, University of Chicago Press.

/// Grigoryev L. 2011. "Elites - the Choice for Modernization," [in:] Russia: The Challenges of Transformation, eds. D. Trenin, P. Dutkiewicz, New York University Press, pp. 191-224, https://doi.org/10.18574/ nyu/9780814785003.003.0007.

/// Groys B. 1992 [1988]. The Total Art of Stalinism: Avant-Garde, Aesthetic Dictatorship, and Beyond, transl. C. Rougle, Princeton University Press.

/// Halmai G. 2019. "Dismantling Constitutional Review in Hungary," Revista di diritti comparati, vol. 1, pp. 31-47.

/// Hays P.V. 2016. "Contested Boundaries: How Scientists Deal with Uncertainty and Ambiguity in Language," [in:] Language as a Scientific Tool: Shaping Scientific Language across Time and National Traditions, eds. M. MacLeod, E. Smirnova, R. Sumillera, J. Surman, Routledge, pp. 74-85, https://doi. org/10.4324/9781315657257-6.

/// Hoffmann C., ed. 2008. Daten sichern. Schreiben und Zeichnen als Verfabren der Aufzeichnung, Diaphanes.

/// Kleeberg B., Suter R. 2014. “"Doing Truth'. Bausteine einer Praxeologie der Wahrheit," Zeitschrift für Kulturpbilosopbie, vol. 8, pp. 211-226, https:// doi.org/10.28937/1000106675.

/// Krauthausen K., Nasim O.W., eds. 2010. Notieren, Skizzieren. Schreiben und Zeichnen als Verfabren des Entwurfs, Diaphanes. 
/// Latour B., Woolgar S. 1979. Laboratory Life: The Construction of Scientific Facts, Sage Publications.

/// Levinson A. 2004. "Inaia Prostota" [The other simplicity], [in:] Opyt Sotsiografii: Statii, Novoe literaturnoe obozrenie, pp. 491-503.

/// Oreskes N., Conway E.M. 2010. Merchants of Doubt: How a Handful of Scientists Obscured the Truth on Issues from Tobacco Smoke to Global Warming, Bloomsbury Press.

/// Pető A. 2020. "Genderforschung in Ungarn,” Ungarn-Jabrbuch. Zeitschrift für interdisæiplinäre Hungarologie, vol. 35(2019), pp. 229-248.

/// Petrov P. 2011. "The Industry of Truing: Socialist Realism, Reality, Realization," Slavic Review, vol. 70(4), pp. 873-889, https://doi.org/10.5612/ slavicreview.70.4.0873.

/// Rabin R.C., Gabler E. 2020. "Two Huge Covid-19 Studies Are Retracted after Scientists Sound Alarms," The New York Times, https://www. nytimes.com/2020/06/04/health/coronavirus-hydroxychloroquine.html, accessed 20.07.2020.

/// Reckwitz A. 2019. Das Ende der Illusionen - Politik, Ökonomie und Kultur in der Spätmoderne, Suhrkamp.

/// Redden E. 2020. "Rush to Publish Risks Undermining COVID-19 Research," Inside Higher Ed, https://www.insidehighered.com/news/ 2020/06/08/fast-pace-scientific-publishing-covid-comes-problems, accessed 20.07.2020.

/// Roudakova N. 2017. Losing Pravda: Ethics and the Press in Post-Truth Russia, Cambridge University Press, https://doi.org/10.1017/9781316817117.

/// Schmid U. 2015. Technologien der Seele. Vom Verfertigen der Wabrheit in der russischen Gegenwartskultur, Suhrkamp.

/// Shapin S. 1992. "Why the Public Ought to Understand Sciencein-the-Making," Public Understanding of Science, vol. 1, pp. 127-130, https://doi.org/10.1088/0963-6625/1/1/006.

/// Smith K.E. 2019. "A Monument for Our Times? Commemorating Victims of Repression in Putin's Russia," Europe-Asia Studies, vol. 71(8), pp. 1314-1344, https://doi.org/10.1080/09668136.2019.1648765.

/// Wittmann B., ed. 2009. Spuren erzengen. Zeichnen und Schreiben als Verfabren der Selbstaufzeichnung, Diaphanes. 
/// Yeung J., George S., Wagner M., Macaya M., Rocha V., Alfonso III F. 2020. "July 16 Coronavirus News," CNN, https://edition.cnn.com/world/ live-news/coronavirus-pandemic-07-16-20-intl/h_6a7fcb4568d5d53614a3 63cf627065e4, accessed 20.07.2020.

/// Zoltán R., Antonowicz D., Jaworska M. 2020. "Lengyel és magyar vezetô testületek a felsőoktásban" [Polish and Hungarian supervisory bodies in higher education], Educatio, vol. 29(1), pp. 92-107, https://doi. org/10.1556/2063.29.2020.1.7.

/// Friedrich Cain - currently affiliated with the Max Weber Centre for Advanced Cultural and Social Studies of the University of Erfurt, Germany. His research interests cover the history of science and the humanities, as well as historical and political epistemology, with a focus on Central, Eastern, and South-Eastern Europe. He is working at present on a history of science studies in the two German states after 1945. His PhD dissertation, Wissen im Untergrund. Praxis und Politik. klandestiner Forschung im besetzten Polen (1939-1945), will be published in 2021, as will be the volume $A$ New Organon: Science Studies in Interwar Poland (co-edited with Bernhard Kleeberg).

ORCID: https://orcid.org/0000-0002-3078-9933

E-mail: friedrich.cain@uni-erfurt.de

/// Dietlind Hüchtker - professor of historical transregional studies at the Faculty Centre for Transdisciplinary Historical and Cultural Studies at the University of Vienna, Austria. Her research is focused on concepts of space, the history of epistemologies and knowledge, rural history, and gender history. She is co-editor of the journals WerkstattGeschichte, Rural History Yearbook, and Zeitschrift für Agrargeschichte und Agrarsoziologie. Her publications include "Traktoristinnen, Rockstars und der polnische James Dean: Die Performativität popkultureller Zeichen in der Volksrepublik Polen" (2018, in L'Homme: Europäische Zeitschrift für feministische Geschichtswissenschaft); Geschichte als Performance. Politische Bewegungen in Galizien um 1900 (2014, English translation forthcoming); Heilig. Transkulturelle Verehrungskulte vom Mittelalter bis zur Gegenwart (2017, ed. with Kerstin Jobst); Überbringen - Überformen - Überblenden: Theorietransfer im 20. Jabrbundert (2011, ed. with Alfrun Kliems).

ORCID: https://orcid.org/0000-0003-3090-2657

E-mail: dietlind.huechtker@univie.ac.at 
/// Bernhard Kleeberg - professor teaching the history of science at the Max Weber Centre for Advanced Cultural and Social Studies of the University of Erfurt in Germany. His current research focuses on the history of social psychology and the historical epistemology and praxeology of truth. He is editor-in-chief of the book series Historische Wissensforschung (Studies in the History of Knowledge) and co-editor of NTM - Zeitschrift für Geschichte der Wissenschaften, Technik und Medizin (Journal of the History of Science, Technology and Medicine). He recently finished his book Standard of Living: History of a Concept (forthcoming in 2021). Among his most important publications are "Bad Habits and the Origins of Sociology" (2015, in Retbinking Order: Idioms of Stability and De-Stabilization, eds. Nicole Falkenhayner et al.); Ernst Mach und das Gedankenexperiment um 1900, special issue of Berichte zur Wissenschaftsgeschichte (2015); “"Doing Truth'. Bausteine einer Praxeologie der Wahrheit" (2014, with Robert Suter, in Wabrheit. Zeitschrift für Kulturphilosophie); Schlechte Angewobnheiten (2012, ed.); Knowing God, Believing Nature, special issue of Science in Context (2007, co-ed. with Fernando Vidal); Theophysis. Ernst Haeckels monistische Philosophie des Naturganzen (2005).

ORCID: https://orcid.org/0000-0002-7299-2331

E-mail: bernhard.kleeberg@uni-erfurt.de

/// Jan Surman - historian of science and scholarship, focusing on Central and Eastern Europe in the nineteenth and early twentieth centuries. Surman holds a $\mathrm{PhD}$ in history from the University of Vienna and has most recently been working at the Herder Institute, Marburg; IFK International Research Center for Cultural Studies Vienna; and the National Research University - Higher School of Economics, Moscow. His research focuses on scientific transfers, academic mobility, and scientific internationalism. His publications include Universities in Imperial Austria 1848-1918: A Social History of a Multilingual Space (2019) and The Worlds of Positivism: A Global Intellectual History, 1770-1930 (2018, ed. with Johannes Feichtinger and Franz Fillafer). He is a founding member of the social media platform hps.cesee: History of Science in Central, Eastern and Southeastern Europe.

ORCID: https://orcid.org/0000-0003-1499-3122

E-mail: jan.surman@gmail.com 